\title{
Review of the provisions of the European Parliament and of the Council Directive 2013/30/UE on safety of offshore oil and gas operations
}

ABSTRACT: The events that took place on April 10,2010 on the Gulf of Mexico began an international debate on minimizing and materializing the risk of dangerous occurrences and accidents during the exploitation of offshore energy resources. In the aftermath of this event to ensure safe operation in European maritime areas, the European Union decided to introduce regulations throughout the entire EU.

On June 12, 2013, Directive 2013/30/EU of the European Parliament and of the Council on safety of offshore oil and gas operations and amending Directive 2004/35/EC was issued. The main aim of the Directive is to reduce the occurrence of major accidents relating to offshore oil and gas operations and limits their consequences. The article is a review of provision of Directive 2013/30/UE with particular regard to requirements at the national level. What is more, the paper indicates solutions which must be introduced by July 19, 2018 in offshore companies. The incorporated solutions must include the protection of the marine environment against pollutions (especially oil spills), establish minimum conditions for safe offshore exploration and the production of oil and gas and improve the response mechanism in the eventof an accident. The paper also presents accidents which take place in oil and gas fields which are a background of necessary improvements of safety during offshore operations.

KEYWORDS: Directive 2013/30/EU, safety of exploitation of offshore oil and gas, geological and mining law

\footnotetext{
${ }^{1}$ Faculty of Command and Naval Operations in the Polish Naval Academy in Gdynia. Deputy Designated Personal Ashore at the LOTOS Petrobaltic JSC (Polish Offshore Company); e-mail: a.mrozowska@amw.gdynia.pl
} 


\section{Introduction}

Conducting activities related to oil and natural gas in sea areas is subject to the risk of major accidents, breakdowns, dangerous situations and other events. The fact is that the threat posed by spilled petroleum in sea areas may pose a threat to the life and health of people not only staying on the installation but also as a result of contact with a contaminated natural environment and degrading it for many years. In addition, threats that occurred in the marine exploitation fields show that they negatively affected the regional and global economy and shaped the exploration and production as well as oil prices on the local and global markets.

The events that took place in the sea exploitation fields and the events of 10 April 2010 on the Gulf of Mexico began an international debate aimed at introducing regulations on the exploration and production of oil and gas in sea areas. In particular, attention was focused on preventive activities consisting in: securing the conduct of works on sea fields, immediate and, above all, proper conduct in the event of a threat and increasing the awareness of threats among the public and entities conducting operations. An important aspect of the analysis of the current security situation in the offshore industry is the fact that the used installations, both underwater and navigational, have already reached the age of 25-30 years and even above, thus approaching the original planned operational periods. Therefore, an aging fleet requires appropriate risk management in order to reduce the number of accidents (including at work) and introduce appropriate safeguards. According to Lloyds List Intelligence, Westwood Global Energy Group installations erected 20 years ago or more constitute: 68\% in Northern Europe, 70\% ,in Latin America, 71\% in North America, 75\% in Africa. In North America, 30\% of the offshore installations and pipelines are 30 years old or more. This forces the introduction of regulations and mechanisms for proper the monitoring of the situation, broadly understood security measures and proper response in the event of an incident (https://www.lloydslistintelligence.com).

The aim of the article is to implement Directive 2013/30/EU of the European Parliament and of the Council on the safety of activities related to oil and gas fields in sea areas and amendments to Directive 2004/35/EC, with particular regard to requirements at the national level. The directive has been developed to reduce the risk of major accidents related to oil and gas. Therefore, it requires the identification and management of serious threats, as well as the introduction of effective response strategies in the event of their occurrence from owners and operators conducting activities related to oil and natural gas. These activities relate primarily to start-up but also existing activities.

The study also presents the analysis of the reasons for introducing regulations aimed at improving safety during drilling and mining energy resources from under the seabed, based on the presented events that took place in the past. They provide the background for presenting a broad spectrum of risks in the offshore industry.

For a better understanding of the topic, the stages of conducting the work are presented and the threats that may be encountered on each of them are outlined, as well as potential threats on the maritime platform. 
The work was written on the basis of international and national regulations on conducting oil and gas work in sea areas and the author's experience related to the implementation of the Directive of the European Parliament and Council No. 2013/30/EU and the implementation of national documents on the basis of the Polish industry exploration and productionof oil and natural gas located under the seabed in Polish maritime areas. The author decided to write this article because she realizes are not many papers on this subject.

\section{Offshore needs and conducting works on exploitation fields as a background for the introduced provisions of Directive 2013/30/EU}

The growing needs of the world economy in ensuring the supply of oil and gas for the proper functioning of industry and transport makes it necessary to search for new sources of their acquisition, transport and the use of more effective security mechanisms.

Increasing the prices per barrel of crude oil and the constant demand for energy raw materials in the world fills with optimism. Together with the expected recovery of the offshore market, new challenges will emerge which, above all at the present time, are aimed at the profitability of projects and the implementation of new regulations in the field of maritime mining.

The development of energy commodity prices is conditioned by many factors, including: economic, political, transport, as well as speculation about the sufficiency of resources. Various types of geopolitical events in the world, such as: crises, wars, natural disasters affect the production of energy hydrocarbons and may also affect the conditioning of their prices (Mrozowska 2011). Rapid changes in the distribution of energy commodity prices may cause disturbances in the global economy. Fluctuations in oil prices have always occurred in the shape of amplitude. Currently, according to the chart, they have a rising tendency. This will become a chance for opening new mining projects as well as those shelved.

The organization of work in the field of exploitation, in order to extract energy resources located under the sea bottom, takes place successively in the following stages, which are presented in a simplified way in Figure 1 (Cydejko et al. 2011).

The first of these is the recognition of the construction of the seabed and the energy resources contained therein, through a geological survey of the seabed. This is a long-lasting process that allows the following to be specified in detail: the structure of the bottom, the accumulation and location of resources, the possibility of drilling trials and extraction of fossil fuels on the surface. Hydrometeorological conditions are also identified. If the collected information confirms the technical and economic possibilities of obtaining them, the second stage begins, in which preparatory activities of the deposit for exploitation are undertaken. At this stage of the field, the development of an analysis of the seabed is carried out in terms of the founda- 
tion of drilling, mining, production and transmission installations. The expected lifetime of the reservoirs is determined, appropriate units, installations and devices are introduced. This is a complex of activities aimed at preparing the field for its exploitation, that is to the third stage. This phase begins with the start-up of the infrastructure and equipment in the operating field, as well as trial and exploitation drilling as a result of which the equipment is checked and the production of energy hydrocarbons starts from under the seabed. The oil and gas produced may also hit the platform, where the initial separation of oil and gas takes place, and the cleaning of solid particles or direct transfer to a warehouse located in the field or further from the recipient takes place. The fourth stage is the development of the exploited reservoir. Various types of innovative technologies are used to improve the efficiency of the reservoir's operation or to improve its efficiency, or allow to obtain more raw material and improve the profitability of the investment.

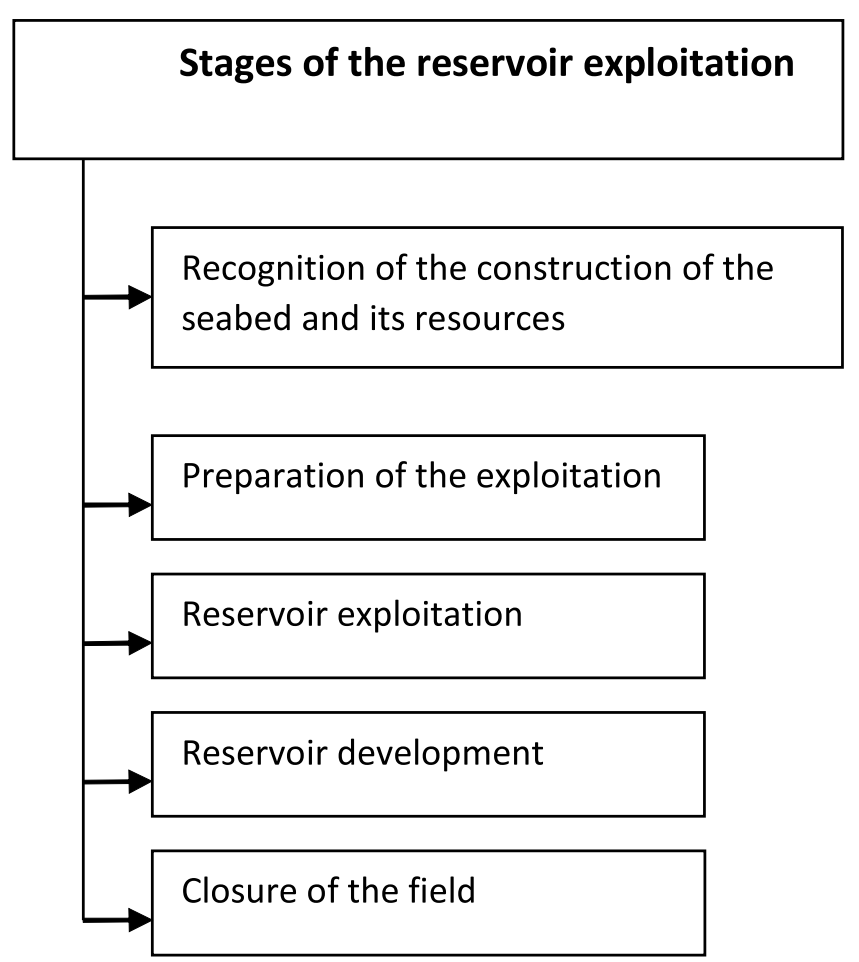

Fig. 1. Stages of work organization in the field of exploitation

Source: own study

Rys. 1. Etapy wykonywania prac

New installations and devices can be introduced, further production wells are carried out, as well as reconstructions of existing wells and other diversified investment works. After the 
depletion of the deposit or the lack of economic justification for further extraction, the well is closed down and secured. Installations, fixed structures and equipment are removed or protected against damage and the field is closed, i.e. the fifth stage takes place.

The specificity of the activities carried out indicates that they are subject to the risk of a threat. Therefore, at every stage of work it is necessary to maintain safety rules and keep it at an optimal and acceptable level throughout the entire operation. Ensuring the level of safety is the result of the synthesis of elements that interact with each other. These include: external factors, technical factors, operational factors, human factors, as well as a number of factors that have a direct and indirect impact on operation, support and disrupt the acquisition process.

During the exploitation phase, oil reservoirs may have the following risks of marine pollution. In the exploratory phase, conducted by the drilling method, an eruption may occur, i.e. the uncontrolled outflow of oil and gas to the surface. Then, during the testing phase of the hole, leakage may occur from the low pressure on-board the system for transferring oil between the on-board equipment. Also in the operational phase an eruption from the exploited well may take place, which may take place in particular during the reconstruction of the production well, leakage from low pressure pipelines serving the oil field, which is located on the seabed, leakage from a non-pressure on-board installation used to transfer oil between the devices on-board, leakage from the installation in relation to the platform, surface and submarine infrastructure including the tanker during transporting oil to the receiving port, as well as during transmission of gas and gasoline to a land receiver, as well as unsealing of high-pressure pipeline, gas and gasoline leak and gas emission to the atmosphere.

Bearing the above threats and events in sea areas in mind, they confirm that there is a risk of a serious threat to the life and health of people staying on the sea platform, for the marine environment and infrastructure (its construction). Table 1 presents the accidents that took place chronologically, in the selection of events the criterion of the definition of major accidents to Directive 2013/30/EU was addressed.

The selected disasters presented above indicate that the conducted activity is exposed to the risk of threats to the natural environment and to people at every stage of the reservoir exploitation.

Failure causes contamination of the sea area both at the accident site and many kilometers from it. It contributes to the disruption of the functioning of the ecosystem, is a real threat to the life of living organisms, but above all to people who are staying in a contaminated environment. The return to the condition from before the disaster takes many years, during which toxic substances enter the natural environment all the time. 
TABLE 1 . The events that took place in the offshore industry according to the definition of major accidents in Directive 2013/30 / EU

TABELA 1. Zdarzenia, które miały miejsce w przemyśle offshore zgodnie z definicją poważnych zagrożeń

\begin{tabular}{|c|c|c|c|c|}
\hline $\begin{array}{c}\text { Place of occur- } \\
\text { rence }\end{array}$ & $\begin{array}{c}\text { Time of } \\
\text { occurrence }\end{array}$ & Name & Results & Causes \\
\hline 1 & 2 & 3 & 4 & 5 \\
\hline $\begin{array}{c}\text { The coast of } \\
\text { Angola }\end{array}$ & $\begin{array}{l}\text { September } \\
28,2016\end{array}$ & $\begin{array}{l}\text { Oil rig heli- } \\
\text { copter } \\
\text { (Chevron) }\end{array}$ & Number of fatalities: 6 . & Machinery damage. \\
\hline The North Sea & $\begin{array}{l}\text { April 29, } \\
2016\end{array}$ & $\begin{array}{l}\text { Super Puma oil } \\
\text { rig helicopter }\end{array}$ & Number of fatalities: 13 . & $\begin{array}{l}\text { Machinery failure. After series } \\
\text { of accidents, flights were su- } \\
\text { spended. }\end{array}$ \\
\hline $\begin{array}{l}60 \text { nautical miles } \\
\text { off the coast of } \\
\text { Brazil }\end{array}$ & $\begin{array}{l}\text { September } \\
12,2015\end{array}$ & $\begin{array}{l}\text { Cidade de Sao } \\
\text { Mateus }\end{array}$ & $\begin{array}{l}9 \text { People were killed, } \\
26 \text { people were injured, the } \\
\text { oil production was less than } \\
10 \% \text {. }\end{array}$ & Increasing of the output. \\
\hline $\begin{array}{l}55 \text { milesfrom } \\
\text { the shores of Lo- } \\
\text { uisiana, in South } \\
\text { Timbalier Area } \\
\text { Block } 220\end{array}$ & $\begin{array}{c}\text { July } 23 \text {, } \\
2013\end{array}$ & $\begin{array}{l}\text { Herkules } 265 \\
\text { Platform }\end{array}$ & $\begin{array}{c}\text { collapse of the Texas and } \\
\text { Derrick deck. }\end{array}$ & $\begin{array}{l}\text { Incorrect calculation of the } \\
\text { drilling mud density by the } \\
\text { drilling crew. }\end{array}$ \\
\hline $\begin{array}{l}\text { North Sea, about } \\
180 \mathrm{~km} \text { from } \\
\text { Aberdeen }\end{array}$ & $\begin{array}{l}\text { August 16, } \\
2011\end{array}$ & $\begin{array}{l}\text { Gannet Alpha } \\
\text { Shell Platform }\end{array}$ & $\begin{array}{l}\text { Oil spill from one of its plat- } \\
\text { forms was limited to } 5 \text { barrels } \\
\text { but the export will be } 88,000 \\
\text { barrels of crude oil per day. }\end{array}$ & An oil leak in a flow line. \\
\hline Gulf of Mexico & $\begin{array}{l}\text { April 20, } \\
2010\end{array}$ & $\begin{array}{l}\text { Deepwater Ho- } \\
\text { ryzont. Transo- } \\
\text { cea Oil-drilling } \\
\quad \text { Platform }\end{array}$ & $\begin{array}{l}\text { About } 5 \text { million tons of oil } \\
\text { got into the water, causing } \\
\text { contamination of the coasts } \\
\text { of the states of Louisiana, } \\
\text { Mississippi and Florida, as } \\
\text { well as the killing of many } \\
\text { thousands of animals. }\end{array}$ & $\begin{array}{l}\text { Sudden increase in pressure in } \\
\text { the deposit and release of hyd- } \\
\text { rocarbon from a badly secured } \\
\text { well and failure to act in the } \\
\text { critical situation of the explosion } \\
\text {-proof head. }\end{array}$ \\
\hline $\begin{array}{l}\text { PetroleosMexica- } \\
\text { nos (about } \\
65 \text { miles from } \\
\text { the coast of the } \\
\text { Tabasco region } \\
\text { near the port of } \\
\text { Dos Bocas. }\end{array}$ & $\begin{array}{l}\text { October } \\
21-24 \\
2007\end{array}$ & $\begin{array}{l}\text { Usumacinta } \\
\text { Platform }\end{array}$ & $\begin{array}{c}22 \text { people died, about } \\
120,000 \text { barrels, out of } \\
442 \text { thousand, got into the } \\
\text { water (the rest was recove- } \\
\text { red). }\end{array}$ & $\begin{array}{l}\text { Extreme weather conditions, the } \\
\text { cold front created a wind speed } \\
\text { of } 130 \mathrm{~km} / \mathrm{h} \text { and } 8 \text { meters of } \\
\text { waves, as a result of which the } \\
\text { deck and production valves } \\
\text { were damaged, there was a leak, } \\
\text { there was a passage of spark and } \\
\text { fire which caused significant } \\
\text { losses in the construction of the } \\
\text { platform. }\end{array}$ \\
\hline Gulf of Mexico & $\begin{array}{l}\text { August } \\
23-31 \\
2005\end{array}$ & $\begin{array}{l}\text { About } 60 \\
\text { platforms in the } \\
\text { area of Hurri- } \\
\text { cane Katrina's } \\
\text { path }\end{array}$ & $\begin{array}{l}\text { Led to the destruction of } \\
\text { almost } 60 \text { platforms, half of } \\
\text { which were completely de- } \\
\text { stroyed. There was a leakage } \\
\text { of about } 200,000 \text { barrels of } \\
\text { crudeoil. }\end{array}$ & Hurricane Katrina. \\
\hline
\end{tabular}


TABLE 1 cont.

TABELA $1 \mathrm{~cd}$

\begin{tabular}{|c|c|c|c|c|}
\hline 1 & 2 & 3 & 4 & 5 \\
\hline $\begin{array}{l}\text { Mumbai High, } \\
\text { Indian Ocean }\end{array}$ & $\begin{array}{l}\text { July } 27, \\
2005\end{array}$ & $\begin{array}{l}\text { Mumbai High } \\
\text { North } \\
\text { Oil and Natural } \\
\text { Gas Corpora- } \\
\text { tion (ONGC) }\end{array}$ & Number of fatalities: 22 . & \\
\hline PersianGulf & 1990 & 350 oilwells & $\begin{array}{l}\text { As a result of these acti- } \\
\text { vities, land and water areas } \\
\text { have been contaminated by } \\
\text { approximately } 5 \text { million } \\
\text { barrels of crude oil. }\end{array}$ & $\begin{array}{l}\text { As a result of military opera- } \\
\text { tions in Kuwait, the Iraqi army } \\
\text { burned oil wells. }\end{array}$ \\
\hline $\begin{array}{l}\text { British helicopter, } \\
\text { Sumburgh coast, } \\
\text { British shelf }\end{array}$ & $\begin{array}{c}\text { November } \\
6,1986\end{array}$ & $\begin{array}{l}\text { Brent Field } \\
\text { Chinook }\end{array}$ & Number of fatalities: 45 & Machinery damage. \\
\hline The North Sea & $\begin{array}{l}\text { June 6, } \\
1988\end{array}$ & $\begin{array}{l}\text { Piper Alpha } \\
\text { oil platform } \\
\text { belonged to } \\
\text { the Occidental } \\
\text { Petroleum } \\
\text { group }\end{array}$ & $\begin{array}{l}\text { A series of explosions took } \\
\text { place, resulting in a fire in } \\
\text { the pipelines of hydrocar- } \\
\text { bons and the sinking of the } \\
\text { structure, causing the death } \\
\text { of } 167 \text { people. }\end{array}$ & $\begin{array}{l}\text { The reason for the explosion } \\
\text { was, among others: the lack of } \\
\text { a valve on the module A gas } \\
\text { compressor and start it after } \\
\text { the failure of the B module gas } \\
\text { compressor, as well as incorrect } \\
\text { communication between the } \\
\text { crew and no decision to close } \\
\text { production on other platforms. }\end{array}$ \\
\hline Iran'swater & 1983 & $\begin{array}{l}\text { oil platform } \\
\text { in the field of } \\
\text { Nawruz }\end{array}$ & $\begin{array}{l}\text { almost } 2 \text { million tons of oil } \\
\text { leaked within a year. }\end{array}$ & $\begin{array}{l}\text { there was a collision between } \\
\text { the ship and the platform. }\end{array}$ \\
\hline The North Sea & $\begin{array}{l}\text { March 27, } \\
1980\end{array}$ & $\begin{array}{l}\text { Alexander L. } \\
\text { Kiellandresi- } \\
\text { dential barge } \\
\text { which was } \\
\text { a hotel for } \\
\text { people working } \\
\text { in the Ekofisk- } \\
\text { field }\end{array}$ & $\begin{array}{l}123 \text { people were killed and } \\
212 \text { evacuated. }\end{array}$ & $\begin{array}{l}\text { During the storm there was a } \\
\text { sinking, as a result of breaking } \\
\text { the crossbars fastening two of } \\
\text { the five carrying supports. }\end{array}$ \\
\hline $\begin{array}{l}\text { The Gulf of } \\
\text { Mexico }\end{array}$ & $\begin{array}{c}\text { June 3, } \\
1979\end{array}$ & $\begin{array}{l}\text { Ixtoc I plat- } \\
\text { form }\end{array}$ & $\begin{array}{l}\text { Over } 3 \text { million barrels of cru- } \\
\text { de oil were injected into the } \\
\text { water. The leak was blocked } \\
\text { after more than } 9 \text { months. }\end{array}$ & $\begin{array}{l}\text { during the drilling a gas explo- } \\
\text { sion took place, as a result of } \\
\text { which the platform sank }\end{array}$ \\
\hline The North Sea & $\begin{array}{l}\text { April 17, } \\
1977\end{array}$ & $\begin{array}{c}\text { EkofiskBravo } \\
\text { platform }\end{array}$ & $\begin{array}{l}\text { there was a hydrocarbon } \\
\text { explosion from the deposit } \\
\text { and } 25 \text { thousand tons of oil } \\
\text { leaking into the water. No } \\
\text { victims. }\end{array}$ & $\begin{array}{l}\text { Eruption and no explosion-pro- } \\
\text { of head that was being repaired } \\
\text { at that time. It was the first oil } \\
\text { spill during the exploitation } \\
\text { of offshore fields in the North } \\
\text { Sea. It encouraged reflection } \\
\text { on providing resources to avoid } \\
\text { similar events in the future. }\end{array}$ \\
\hline
\end{tabular}

Sources: own study supported by website (www.lloydslistintelligence.com, www.marineinsight.com) and own experiences. 


\section{The provisions of the $2013 / 30 /$ EU Directive}

The introduction of the Directive 2013/30/EU aims to reduce the risk of hazards by defining the framework of activities for EU Member States conducting mining operations and, above all, obliging operators and owners to implement appropriate solutions in this area. The Directive lays down minimum requirements in the area of major-accident prevention related to oil and gas activities in maritime areas. This applies to works related to the operation of installations for exploration and production of energy resources in sea exploitation fields. It does not specify the rules for their transport.

It seems that this can be the most effective means to regulate issues related to the safety of operations as well as to protect the marine environment from its degradation due to the entry of additional toxic agents as a result of exploration, drilling and oil and gas production. However, there is a risk that the ambiguities resulting from it and the improper implementation of it on the local ground may not bring the expected results. However, it should be emphasized that this is undoubtedly a milestone in the unification of regulations in the area of business.

As already mentioned, the entry into force of the provisions of the Directive coincided with the recovery of the offshore market. At present, there are at least 1,000 oil and gas operations from the seabed currently operating off the coast of Europe, according to Det Norske Veritas. The risk associated with major accidents can be assumed to exist. It should be emphasized that $80 \%$ of oil and gas production in Europe is located in fields located in sea areas. According to data from January 2018, 184 platforms are located in the North Sea (statistic.com/statistic). The remaining number of sea platforms (offshore installations) is shown in Figure 2.

\section{Number of offshore rigs worldwide}

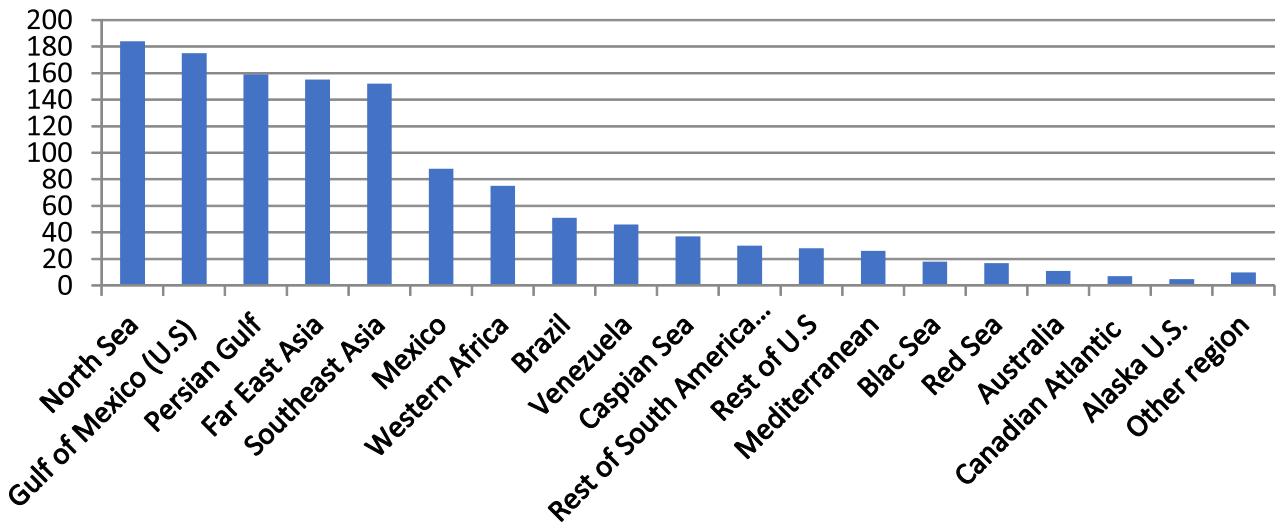

Fig. 2. Number of offshore rigs worldwide

Sources: Own study on the base date (https://www.statista.com/)

Rys. 2. Liczba morskich platform na świecie 
Undoubtedly, the extraction of raw materials is an important element of the safety of the marine environment protection and ensuring the safety of working conditions.

The Directive consists of nine chapters with forty four articles and eights annexes.

The first chapter refers to general information and describe definitions which are the base to a proper understanding of particular issues such as major accidents and hazards.

Chapter II of the Directive discusses the prevention of major accidents related to the activity of oil and gas fields in sea areas, which mean ensuring risk management carried out in activities.

The foundation of the Directive is to regulate the issue of who can perform work in offshore mines, ensuring that the activities carried out are performed by operators designated by concession authorities and after prior approval (Article 4).

Article 5 emphasizes that new drilling operations cannot be set up before giving suitable permission by the Authority.

Article 6, entitled: Activities related to oil and gas fields in the licensed areas, also states that (...) "Member States shall ensure that production installations and connected infrastructure are operated only in licensed areas and only by operators appointed for that purpose".

An interesting record is the possibility of public participation in relation to the environmental effects of the exploration activity related to oil and gas fields in sea areas. This means that no activity can be started without prior social consultation regarding the possible environmental impacts on planned activities related to oil and gas fields in maritime areas under other Union legislation. The regulations gave the opportunity to designate mining authorities responsible for the control of operations in the event of any doubts. This means for example, Sweden may ask for safety in conducted works in Polish or Norwegian sea areas. Tripartite talks within the company are also conducted to ensure safety.

Operators (not only owners or countries where work is being carried out) have been required to ensure that all appropriate measures are taken to prevent major accidents as a result of activities related to oil and gas fields in maritime areas. The Directive indicates that operators will not be released from their duties connected with the hazards. Also, that they bear full financial responsibility for damage done to the environment as well as bear the costs associated with the prevention of damage to the environment during work (Article No.7). Another article in this chapter refers to task and function of the competent authority.

Chapter III indicates regulations for the proper preparation and carrying out offshore oil and gas operations. That means that Article 11 describes documents to be submitted for carrying out operations. The operator or the owner must prepare documentation that must be submitted to the competent authority in connection with its operations, namely:

1. Corporate policy in the area of major accident prevention.

2. Safety and environmental management system.

3. Reports on the activities carried out at least once every 5 years, which may be considered negatively by the competent supervisory authority and activities may be suspended.

4. Internal plans and including them in external response plans.

5. Describing of establishing an independent verification system to verify the correct functioning of the system, as confirmation of the key organisms for safety and the environ- 
ment, but will not be able to suspend activities, only provide advice and opinions that the operator should take into account and the competent authority has an insight.

6. Confirmation of financial responsibility for preventing damages as well as their liquidation - not only in the waters on which the activity is carried out.

7. Confirmation of significant changes in the installation.

8. Mining plant work plan with attachments, among others: organizational structure of the mining plant, specifying the positions of management and labor supervision, plan to prevent oil spills and the elimination of environmental hazards, coordinated with the National Plan for Opposing Sea Environment Dangers and Contaminations, agreed with the appropriate body of maritime administration and the Maritime Search and Rescue Service, fire hazard and explosion hazard zones, bathymetric maps of the bottom as well as plant layout diagrams.

In its abundance of provisions, the Directive first of all wants to ensure that everyone who conducts business will implement harmonized rules to be imposed on all platforms, actions to take appropriate measures to prevent major accidents, i.e. complete supervision and responsibility over the conducted activities even if it is performed by another operator.

For this purpose, each entity conducting activities must present technical and financial capacity to conduct such a highly specialized and risky business in which a number of threats can occur. An important element is the possibility for public administrations to participate in relation to their activities, it is possible to identify the operator if they actually have adequate safety provisions and are adequately prepared to act in the event of possible consequences.

In order to ensure preparation for action in an emergency situation, entities have to develop internal response plans in case of an event that are included in external response plans, according to the provision in Article 14.

A key element of the plans are the developed risk assessments and the analysis of the effectiveness of the emergency response.

The competent authority must be notified of any activity before commencing work on the borehole. The entity must report on planned well operations that contain details of the well design and proposed well operation in accordance with the requirements set out in Part 4 of Annex I, which includes an analysis of the response effectiveness in the event of an oil spill.

In addition, the company must establish a safety and environmental management system that is incorporated into the overall management system. It should be noted that in addition to the requirements of the directives, the entity must comply with a number of international and local standards, related to the exploration and production of energy resources located under the seabed in Polish maritime areas, such as: The International Convention for Safety Of Life At Sea (SOLAS Convention), The International Convention for the Prevention of Pollution from Ships (MARPOL Convention), The International Convention on Standards of Training, Certification and Watch keeping for Seafarers (STCW Convention), The Code Mobile Offshore Drilling Units (MODU Code), The International Management Code for the Safe of Ships and from Pollution Prevention (International Safety Management Code), The International Ship and Port Facility Security Code (ISPS Code), The Life-Saving Appliances Code (LSA Code), The Fire Safety 
System Code (FSS Code) and numbers of others to meet the requirements of environmental standards related to health and safety at work, quality management and resulting from mining regulations.

The most important aspects of ensuring effective activity in an emergency situation is reporting as soon as possible, in particular if they are classified as major hazards.

To ensure the highest level of safety, Article 17 refers to independent verifications that every operator must establish. This is done to give independent assurances that safety and environmental critical elements identified in the risk assessment for the installation are described in the established documents (intended).

Chapter IV refers to prevention policy. Article 19 of the Directive requires the development of a corporate policy for the prevention of major accidents, ensuring that this policy is implemented in all aspects of their activities related to oil and gas fields in sea areas, including the introduction of appropriate monitoring mechanisms to ensure the effectiveness of this policy. Where the operation carried out by the operator or owner poses an immediate danger to human health or significantly increases the risk of a major accident, Member States shall ensure that the operator or owner takes appropriate measures that may, if necessary, include the suspension of the operation concerned until the hazard or the risk will be under proper control. Member States shall ensure that, where such measures are taken, the operator or owner, promptly and no later than 24 hours after taking those measures, notify the competent authority in the so-called extraordinary manner and not within three days as other events. In the Polish law, this has already been regulated in the Geological and Mining Law.

The regulations also concern:

1. Conducting works on permanent and mobile installations, from the design and planning phase of works to the liquidation and shutdown of installations;

2. Analyzing and prevent serious threats by identifying preventive measures and methods. It consists of setting goals and achieving them;

3. Conducting a risk assessment and identifying possible event scenarios;

4. Implementation of reliable management systems;

5. Developingan effective corporate policy in the scope of safety and the environment linking the functioning of security systems and emergency response plans;

6. Operating on a wellbore should only be carried out by installations technically capable of controlling all anticipated hazards that may occur at the well site, assessed by an expert.

Current industry practices indicate that the rules that were laid down before the Directive came into force did not sufficiently ensure a significant reduction in the risk of failure and liability and covering the costs of removing damages. An important issue is to determine the responsibility for the business and to have financial security in the event of damages and cover all costs of claims handling.

Another one describes transparency and the sharing of information. They establish ways of changing information, communication, reporting and investigating following major accidents including: oil spills, helicopter disasters, collisions, fatalities and others which are described in Annex nine. 
One of the most important thing to ensure early prevention is cooperation between Member States. Chapter VI establishes regulations to ensure a regular exchange of knowledge, information and experience between Each Member States and the European Union Offshore Oil and Gas Authorities.

Chapter VII describes requirements which refer to prepare an internal emergency response plan by an operator or owner, external emergency response plans by the Member States and suitable emergency responses in the event of hazards. This means, in practice that the operator or owner must integrate all existing measures and plans related to protection and rescue personnel on the installation and its surroundings. All the relevant information that is included in the internal emergency response plan must be prepared in accordance with Annex I. According to Article 29, an external response plan must be prepared with the most up to date version of the internal emergency response plan of the existing and planned installations. The basis of proper and effective reactions in the event of an emergency is to corporate and ensure support to reduce the consequences, in particular oil spills. So the Member State according to Article 30 must provide assistance with supplying additional measures. The Equipment Assistance Service (EAS) consists of stand-alone oil pollution response equipment stockpiles in selected areas around Europe. The EAS equipment is on a stand-by basis, ready to be mobilized around-the-clock anywhere in European waters and shared sea areas. There is a storage facility in Gdansk which is equipped with special set of stock piles for the East South Baltic Sea Region (Table No. 2).

TABLE 2. Oil spill facilities for the East South Baltic Region

TABELA 2. Sprzęt zwalczania rozlewów olejowych dla obszaru Bałtyku południowo-wschodniego

\begin{tabular}{|c|c|c|c|c|c|c|}
\hline $\begin{array}{c}\text { Oil Pollution Region } \\
\text { Equipment }\end{array}$ & $\begin{array}{c}\text { Fire } \\
\text { Boom }\end{array}$ & $\begin{array}{c}\text { Speed } \\
\text { Sweep }\end{array}$ & $\begin{array}{c}\text { Current } \\
\text { Buster }\end{array}$ & $\begin{array}{c}\text { Roboom-Roskim } \\
\text { Integrated System }\end{array}$ & $\begin{array}{c}\text { Trawl Net } \\
\text { System }\end{array}$ & $\begin{array}{c}\text { Lamor LFF400 brush } \\
\text { skimmer }\end{array}$ \\
\hline $\begin{array}{c}\text { No. of sets in } \\
\text { EAS Baltic Sea }\end{array}$ & 4 & 2 & 1 & 1 & 2 & 1 \\
\hline
\end{tabular}

Source: http://www.emsa.europa.eu/oil-spill-response/eas-inventory.html.

Chapter VIII refers to take major hazards which can have significant effects on the other Member States. So the relevant information should be established and kept. Additionally, each Member State should adopt measures to prevent damages in the event of pollution.

The last chapter regulates penalties and final provisions. More details referring to preparing documentation by the operator and an explanation regarding what information should be submitted are in the annex at the end of the Directive. 


\section{Implementation of regulations in Polish maritime areas}

On January 1, 2018, in accordance with the announcement of Speaker of the Lower House of the Polish Parliament of October 16, 2017 regarding the publication of a uniform text of the Act - Geological and Mining Law (Journal of Laws of 2017, No. 2126), the provisions of Directive 2013/ 30/EU entered into force in Poland, noting that by July 19, 2018 entities carrying out oil and gas related activities in sea areas must implement its provisions. The provisions were to be implemented by relevant acts on the basis of individual member states.

All national companies must meet the requirements which are implemented by the national law. The national regulations should include relevant information referring to the European requirements. However, not all of them were implemented, for example there is no regulation for independent verification.

These are the most important changes which were implemented according to the provisions of the Directive into the Polish Geological and Mining Law:

1. Introduction new criteria for major risks and major hazards referring to activities (Article $49 \mathrm{~m}$ point 1a).

2. Liability for the environmental damages. This means that the operator or owner must have financial liability to cover all environmental damages and claims (kept in an independent bank account in the event of an emergency. The amount of money should be calculated according to the license (Article 49x point 9a).

3. Chapter XII refers to checking the technological and organizational solutions connected which refer to gas and oil searching, exploitation and production.

4. Mining plan operations must include extra information such as risk assessment, major accidents, safety and environmental management system, independent verification, social consultations, tripartite talks, frequency of reviewing documentations and obligatory passing into the suitable Mining Authority.

5. And others such as: operator's statement that the works are carried out with suitable safety procedures, analyses of the effectiveness of an emergency response in the event of oil spills, the opinion prepared after independent verification by an independent expert, establishing a corporate major accident prevention policy.

6. In case of any doubts the Mining Authority can suspend operation and inform the Member State. Any change in the Mining Plan Operation must be accepted by the Mining Authority. Article 108 point 10.

7. The operator or owner must incorporate an independent verification system which must be included to the safety environmental management system

8. The Mining Plan Operation is checked by the Independent Expert and all his remarks must be taken into account by the operator and all explanations must be implemented and as soon as possible and passed to the suitable Authority. 
9. The Rescue Mining Plan is prepared on the base risk assessment and preparedness response in the event of an emergency.

10. New reporting system in the event of an emergency.

11. The regulation increases the actions taken by the President of the Mining Authority.

12. Other information refers to exchanging information and cooperation between national ministry departments and other EU Member States.

All the above changes must be introduced by July 19, 2018 for operators to be able to carry out any offshore activities. No activities can be conducted without this set of documents. The EU added more details which must be done not to repeat the disaster from 2010 in the Gulf of Mexico because the investigation indicated a number of irregularities, the lack of documentation and proper technical measures. The EU obligated all the Member States to introduce all the relevant regulations to protect the environment from pollution and prepare effectives activities in the event of an emergency situation.

\section{Changes after implementing the Directive to national law}

The provisions of the Polish act pose a great challenge for the correct implementation of the provisions due to inconsistencies and content that is questionable. It should be emphasized that Polish entities involved in conducting exploration and production operations in Polish maritime areas, conduct their activities based on the existing regulations and perform them with due diligence, thus ensuring the safety of the works carried out. In order to comply with a number of regulations, having already implemented security systems, mining operations must re-execute provisions, often duplicate already implemented solutions to meet the requirements of the provisions.

An example may be a number of provisions implemented as part of prevention, which is implemented in accordance with the guidelines for many years contained in the Geological and Mining Law of 2011, Ordinance of the Minister of Economy of April 25,2014 on Specific Requirements for Mining Plant Operations Extracting Minerals Drilling Holes (Journal of Laws of 2014, item 812), Regulation of the Minister of Energy of March 16,2017 on Mining Rescue (Journal of Laws of 2017, item 1052) and Regulation of the Minister of the Environment of January 29, 2013 on Natural Hazards in Mining Plants.

To ensure the continuous and safe operation for each Mining Plant, the Mining Plant Movement Manager is appointed, who is directly responsible for conducting the Mining Plant Movement and for controlling the risk of dangerous events or accidents, hereinafter referred to as a risk.

The Head of the Mining Plant Movement with the use of subordinate services performs its tasks and appoints positions responsible for the control of individual risks. 
A Polish company involved in the exploration and extraction of crude oil and natural gas in Polish maritime areas and any entity seeking to start operations must act on the basis of the provisions of the Geological and Mining Law. By implementing it through a series of organizational, technical and financial measures through the implementation of the system and, above all, proper risk management of major accidents. And all this is subjected to verification by an independent expert, appointed in accordance with the provisions of Geological and Mining Law Chapter 4, point XII.

Each entity operating in sea areas or wishing to commence must ensure that there is a continuous and safe activity consisting in the exploration, identification or extraction of hydrocarbons from deposits in the maritime areas of the Republic of Poland.

Operators are required to develop and implement corporate policy in the area of the prevention of dangerous incidents and accidents, in accordance with the requirements of Geological and Mining Law, Article 108 point 9a in light of the Regulation on the detailed scope of the Corporate Policy in the area of prevention of dangerous occurrences and accidents, and taking into account EP and Council Directive 2013/30/EU.

The Corporate Policy is the core of a functioning system of managing safety and environmental protection. Therefore, it is an overriding element, which all employees base in the implementation of their decisions. In order to check whether the developed policy is properly implemented and its objectives are implemented in a proper manner, the company is verified by an independent expert who has control over this policy:

a) rules for controlling the risk of the occurrence of hazardous events and accidents, in terms of risk minimization and materialization;

b) the scope of internal documents regarding the control of the risk of occurrence of dangerous events and accidents;

c) the procedure for carrying out risk control, taking into account:

$\checkmark$ conducting business by the Company,

$\downarrow$ organizational structure of the entrepreneur and mining plants used to carry out the activity,

$\checkmark$ conclusions resulting from the findings on the facts and causes of dangerous events, and accidents, in particular from findings made by mining supervision authorities,

$\checkmark$ measures to identify and assess risks in a transparent manner that ensures reliable risk data,

$\checkmark$ the way of documenting risk control,

d) ways to improve the rules for conducting risk control,

e) corrective actions taken to improve risk control,

f) principles of monitoring the effectiveness of the Corporate Policy:

$\checkmark$ by indicating in the organizational structure of the entrepreneur and mining plant, the responsibility for collecting and transferring information to the entrepreneur regarding: problems encountered while conducting risk control and the effectiveness of the Conceptual Policy.

g) principles and means of functioning in the company of the training and motivational system of employees to report any irregularities and to appreciate the correct attitudes in the area of risk minimization,

h) information on access to up-to-date risk information, 
i) information on the availability of the Corporate Policy,

j) the scope of responsibilities of persons responsible for ensuring the safe operation of the Company consisting in the prospection, exploration or extraction of hydrocarbons from deposits within the maritime areas of the Republic of Poland, and minimizing the risk of dangerous occurrences and accidents as well as proper actions aimed at eliminating the consequences,

k) activities in the area of risk control as well as its improvement and documentation.

In addition, the business entity must develop an independent verification system that confirms that the key elements to ensure the safety of people, the environment and property at the station are adequate and implemented in accordance with the assumptions adopted by the Company, and the implemented projects and conducted works on the wellbore are suitable at every stage of the work. For this purpose, the Mining Plant's Movement Plan together with all attachments and the Corporate Policy are submitted for approval.

To carry out due diligence and in accordance with the law, verification of the conducted activity, an independent experthas to:

$\downarrow$ have appropriate qualifications and technical (mining) competences as well as professional experience in the area that he or she researches,

$\checkmark$ be independent of the verified entity,

$\checkmark$ not to give an opinion on the mining plant's element of operation in the scope in which he or she has participated,

$\checkmark$ be on the list specified by the State Mining Authority.

One of the drawbacks of these provisions is the failure to determine the fees for carrying out such a verification, which must necessarily pass the entity to conduct business. Without an independent verification of the mining plant's plan of operations and the implemented corporate policy, it is not possible to conduct operations. The opinion of the expert is forwarded to the Mining Office.

The system check carried out by an appraiser will consist in the examination of technical and organizational solutions covering the conducted activity, and in particular testing:

1) key elements for the safety of people and the natural environment,

2) operating systems based on international and national regulations operating in the company, verification of the scope of activity conducted by the company,

3) reporting accidents, dangerous and potentially dangerous situations, both inside the company and external institutions,

4) take corrective actions in the eventof finding non-conformities, accidents, dangerous situations detected during internal and external supervisions (all audits and inspections),

5) effectiveness of the implemented corporate policy,

6) installations (technical means) with the related infrastructure,

7) identification of all serious threats and the estimation of the likelihood of their occurrence, taking the impact of factors of the marine environment into account,

8) preparation for taking actions in case of risk of serious threats.

According to the provisions of the Directive, the entity will have to undergo independent verification once every 5 years. However, the Geological and Mining Law does not specify such 
a provision. It is a fact that due to the regulations in force, the first verification must be carried out before July 19, 2018. During the inspection, the expert cannot suspend operations or stop works, but only checks the operation of the systems and prepares a report. The entity should take into account the advice included in the report and take appropriate action, and at the request of the competent Mining Authority, may submit it for verification.

\section{Assessment of safety of oil and gas exploitation and production from reservoirs in the Baltic Sea after implementing Directive 2013/30/UE}

The Directive seems to be one of the great steps in oil and gas operations improvement safety. The first stage is to basically define the major hazards which can happen during explorations and productions and after that prepare protective measures by the operator or owner as well as the Member States. Moreover, the regulations describe who can receive a license for mining operation sand no one can be exempt from responsibility including financial liability.

An important aspect of the ensuring safety of operations is the determination of the risk of serious threats. This means that the entity must identify potential hazards, develop and implement procedures and instructions in accordance with the relevant requirements, define technical and organizational measures to reduce the risk of hazard to a level as low as possible, according to the principle - as low as reasonably as practicable - assess the effectiveness of preventive actions taken, strive for continuous improvement of safety, environmental protection and occupational health and safety, determine the principles of improving employees' skills, raise awareness among employees, and appreciate the right attitude to reporting any dangerous situations and any irregularities to detect them at an early stage.

Risks are assigned to those responsible for managing them, they are to ensure risk management and provide organizational and financial resources for effective management. They carry out continuous risk control, identify and evaluate, analyze risk-related events, monitor minimization methods and, above all, undertake organizational, technical and other activities to reduce risk and improve control. The basic aspect of safety is the involvement of all employees of the entity in monitoring the work environment and the early detection of threats, i.e. each employee is responsible for risk management in the area of their competences, in particular for preventing threats in the scope of performed tasks, as well as reporting any events. The chart on graph No. 2 presents selected key risks that may occur during mining operations.

A number of risks are recognized:

$\downarrow$ The risk of a threat of force majeure, resulting in a difficult implementation of the objectives set, caused by war or crisis,

४ The risk of uncontrolled flow to the hole, hole failure, 
$\downarrow$ The risk of maritime collision,

$\downarrow$ The risk of fire/explosion,

$\checkmark$ The risk of the environmental contamination,

$\downarrow$ The risk of an aircraft accident while transporting employees, resulting in loss of health and life,

$\downarrow$ The risk of limiting the availability of equipment and mining infrastructure due to limited durability or improper operation.

To ensure the limitation of damages to the environment, regular checks and measurements of all process parameters and activities having a significant impact on the environment are ensured. Monitoring is ensured by continuous or periodic measurements of process parameters and activities related to significant environmental aspects, environmental goals and tasks and compliance with legal requirements regarding environmental protection. The main environmental aspects associated with a major accident are: the aspects resulting in the release of hydrocarbons into the environment, reservoir fluid leakage due to loss of control over the wellbore, fire on the platform, environmental aspects related to damages to the installation, environmental aspects related to the exposure of employees to health and life loss (above 5 people).

The control of the above hazards takes place at every stage of work, starting from identifying the workplace, through performing duties and acting in the event of a threat, as well as conducting inspections starting from the positions with the least risk of a threat through a significant risk of failure.

The identified major hazards and organizational arrangements for their control have been introduced. The potential threat states have been identified on the offshore platform:

$\downarrow$ fire/explosion on the platform,

$\checkmark$ eruption,

$\downarrow$ gas release,

$\uparrow$ evacuation,

^ lifting operations,

$\downarrow$ man overboard,

$\downarrow$ oil spill,

$\downarrow$ cooperation of a rescue ship with a platform,

$\checkmark$ damage to the platform installation construction,

$\checkmark$ helicopter disaster (on the platform/fall near the platform),

$\checkmark$ medical evacuation,

$\downarrow$ black out,

$\downarrow$ evacuation of people from a closed space,

$\checkmark$ an accident during the dive.

In the event of a threat condition on the offshore platform, the proceedings are carried out in accordance with the instructions of the proceedings and the records in the alarm schedule and information included in the mine rescue plan, to provide the necessary support from the land during the occurrence of a threat condition on the platform. 


\section{Discussion}

Thelong-term practice of acquiring energy resources from the seabed shows that the goal for an entity dealing in the acquisition and production of energy resources under the seabed should be to create safe working conditions for employees, avoiding the degradation of the natural environment and damage to technical infrastructure - preventing catastrophes and dangerous events that have already been outlined above. In addition, creating such conditions that allow for the proper performance of specific tasks, the prevention of accidents at work, preparation for action in emergencies, taking action to minimize the effects of a dangerous situation and appropriate measures to prevent their occurrence. However, cutting costs caused by the offshore crisis does not improve safety in the offshore industry.

In order to provide the above elements of safety it is necessary to implement legal regulations, prepare crews employed on offshore installations and in a land base, to take immediate rescue action, perform their tasks both during daily use and during an emergency situation and continuous improvement of their skills for the full realizing the tasks entrusted to themin a practical manner. The entity establishes safeguards against the unsafe aspectsidentified by it, i.e. by developing and implementing appropriate procedures. The introduced legal requirements regulating the principles of sea area exploitation, applied modern technologies, equipment and construction solutions, ensuring the proper working conditions and proper service of marine units, as well as the protection of the natural environment, are designed to improve working conditions at sea, enable the early detection of irregularities, liquidation and minimizing the negative effects of a dangerous event, and thus improving safety at sea.Despite the existing regulations, all the time dangerous events occurred that threaten employees, the marine environment and living organisms in it, and cause various types of damage to the maritime infrastructure proving that the issue of safety is still valid. In the near future, it will turn out whether the solutions proposed by the authorities work in practice and whether they are not just records on paper without being implemented in practice.

In connection with the above, ensuring the safety of operations in sea areas should be considered in the dimensions of a complex system in which they interact: the marine environment, infrastructure located in its areas together with the raw material/cargo extracted from the seabed and personnel involved in their operation (Kobyliński 2010). These elements are also related to various defined external complications, which have a direct or indirect impact on the functioning of the system and maintaining the level of safety (Jagniszczak 2010). The interactions are shown in Figure 3.

The system approach to maintaining the level of safety at sea, facilitates its adequate assurance by tying and interconnecting all the elements of the system, as well as indicating irregularities giving a full picture of its functioning.

Managers having lessons learned in recent years by the offshore industry, started to apply a new approach to ongoing work and projects, including economic aspects, but in connection with the introduction of new regulations leaned more on the safety aspects of the business. 


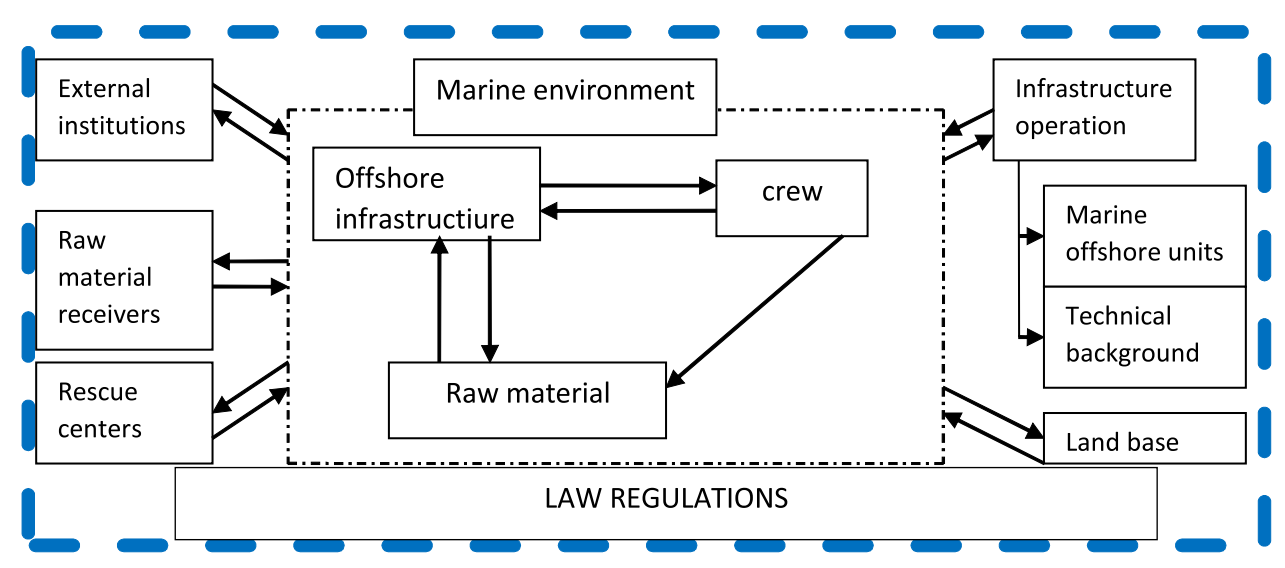

Fig. 3. Interaction of system elements in sea areas

Source: own study

Fig. 3. Wzajemne oddziaływanie elementów systemu na obszarach morskich

Remembering to prevent cost cutting in such a way as to increase the risk of an accident or a serious breakdown, one should introduce safety culture principles, learn each other's actions and be aware of events around us, not only focusing on the tasks performed, but look more broadly and at an early stage, detect any irregularities, thus reducing sensitive points of exploration and production.

\section{Conclusion}

The extraction of energy resources is a highly specialized and dangerous process of acquiring valuable energy minerals from the depths of the earth. The depletion of reservoirs located on land and near the coast causes the transfer of exploitation deep into sea areas. It should be emphasized that with declining number of energy resources, it is aimed at quick extraction and economic profits of corporations. This is connected with the creation of various negligence and unfavorable factors affecting the safety of offshore mining systems.

Each stage of exploitation of offshore reservoirs may lead to various dangerous events, among others: major accidents, equipment failures, machinery damage, accidents at work, fire, explosion, oil spillage, collision, damage to infrastructure construction located on the field and their anchoring system, variable weather conditions and other events such as transshipment and the transport of crude oil. The following can take place as a result of their occurrence: threatened human life, polluted marine environment, damaged infrastructure located in the field of exploitation, it can also create significant technical, economic and environmental losses. 
The development of advanced technologies and various types of failures and accidents that took place in the future influenced the intensification of works on improving safety in the offshore industry and on operating with less losses to the natural environment. However, dangerous events occur all the time.

Let's hope that the implemented Directive will bring positive results in the near future by the limited numbers of dangerous events, oil spills or major accidents. In addition, the documentation established by offshore companies will not be empty documents, but only define practical and real actions in the field of ensuring and improving safety operations in the marine oil fields.

An important aspect of the safe operations is the fact that the Polish offshore company did not have to create new solutions in the scope of documenting the work carried out, but only had to collect its documentations into one whole with the use of appropriate terminology used in the legal regulations. Of course, this took a lot of time and many days of hard work. However, it confirmed that the company meets the requirements of Directive 2013/30 EU. The provisions of the Directive will be developed in the nearest future as the author realizes that the subject has not been exhausted.

\section{References}

CYDEJKO et al. 2011 - CYDEJKO, J., PUCHALSKI, G. and Rutkowski, 2011. Units and offshore technology in a scope (Statki i technologie of-shore w zarysie). Gdynia: Publish by Trademar (in Polish).

Directive 2013/30/EU of the European Parliament and of the council of 12 of June 2013 on safety of offshore oil and gas operations and amending Directive 2004/35/EC. L.178/66 official Journal of the EU 28.6.2013.

Geological and Mining Law Act of 09 June 2011. Journal of Laws of 2017, item No. 2126 the provisions of the Directive 2013/30/EU entered Poland.

International Safety Management Code ISM Code and guidelines on implementation of the ISM Code 2014 Edition, London, IMO London 2014.

JAGNISZCZAK, I. and ŁUSZNIKOW E. 2010. Safety of navigation (Bezpieczeństwo nawigacji). Wyd. Fundacja Promocji Przemysłu Okrętowego i Gospodarki Morskiej, Gdańsk (in Polish).

KoBYLIŃSKI, L. 2001. Basics and philosophy of safety in shipping (Podstawy i filozofia w żegludze). Technical University of Gdańsk, pp. 1-22 (in Polish).

MrozowSKA, A. 2011. Organization of working during exploration energetic resources, which are located under the seabed (Organizacja wydobycia surowców energetycznych usytuowanych pod dnem morskim). Polish Naval Academy Scientific Paper no. LII nr 4(187), pp. 237-256 (in Polish).

Ordinance of the Minister of Economy of 25 April 2014 on specific requirements for mining plant operations extracting minerals drilling holes. Journal of Laws of 2014, item 812).

Regulation of the Minister of Energy of 16 March 2017 on mining rescue (Journal of Laws of 2017, item 1052).

Regulation of the Minister of the Environment of January 29, 2013 on natural hazards in mining plants.

The announcement of Speaker of the Lower House of the Polish Parliament of October 16, 2017 regarding the publication of a uniform text of the Act Geological and Mining Law Act of 09 June 2011.

[Online] http://www.emsa.europa.eu/oil-spill-response/eas-inventory.html [Accessed: 2018-07-01].

[Online] https://www.lloydslistintelligence.com/ [Accessed: 2018-05-16]. 
[Online] https://www.statistic.com/statistic/279100/numer-of-offshore-rigs-worldwide-by-region [Accessed: $2018-05-16]$.

[Online] https://www.marineinsight.com [Accessed: 2018-06-22].

Alicja MrOzOwSKA

\section{Wprowadzenie w życie postanowień Dyrektywy PE \\ i Rady w sprawie bezpieczeństwa działalności związanej ze złożami ropy naftowej i gazu ziemnego na obszarach morskich}

\section{Streszczenie}

Wydarzenia, które miały miejsce w dniu 10 kwietnia 2010 roku na Zatoce Meksykańskiej rozpoczęły międzynarodową debatę w zakresie minimalizacji, jak i materializacji ryzyka wystąpienia niebezpiecznych zdarzeń i wypadków podczas eksploatacji podmorskich złóż surowców energetycznych. Po tym wydarzeniu, dla zapewnienia prowadzenia bezpiecznej działalności na obszarach morskich, Unia Europejska postanowiła wprowadzić regulacje na terenie całej Wspólnoty. W dniu 12 czerwca 2013 roku została wydana Dyrektywa Parlamentu Europejskiego i Rady nr 2013/30/UE w sprawie bezpieczeństwa działalności związanej ze złożami ropy naftowej i gazu ziemnego na obszarach morskich. W artykule przedstawiono implementację jej postanowień na obszarach morskich, ze szczególnym uwzględnieniem polskich obszarów morskich. Przedstawiono główne postanowienia tego dokumentu, krajowe regulacje prawne wprowadzające na grunt polski postanowienia Dyrektywy oraz rozwiązania w zakresie wdrożenia wymogów do 19 lipca 2018 roku w przedsiębiorstwach zajmujących się prowadzeniem działalności związanej ze złożami ropy naftowej i gazu ziemnego na obszarach morskich.

SŁOWA KLUCZOWE: Dyrektywa 2013/30/UE, bezpieczeństwo eksploatacji podmorskich złóż ropy naftowej i gazu ziemnego, prawo geologiczne i górnicze 